\title{
Emotional Quotient and Creative Thinking Skills in Mathematics
}

\author{
Syaiful ${ }^{*}$, Kamid, Muslim, Nizlel Huda, Amirul Mukminin, Akhmad Habibi \\ Faculty of Teaching and Education, Universitas Jambi, Indonesia
}

Received November 23, 2019; Revised December 23, 2019; Accepted January 16, 2020

\begin{abstract}
Copyright $\bigcirc 2020$ by authors, all rights reserved. Authors agree that this article remains permanently open access under
\end{abstract} the terms of the Creative Commons Attribution License 4.0 International License

\begin{abstract}
Purpose: Creative thinking and emotional quotient of students are needed in 21 st century learning, the fact that the acquisition of these two problems is still low. Therefore, associative quantitative research aims to determine whether there is a relationship between students 'emotional quotient and students' creative thinking. Methodology: Using descriptive research. Where the number of all samples from this study was 82 students, where they are selected using a purposive sampling technique, data were then analyzed with the help of SPSS 21 application to find descriptive statistics in the form of mean, min, max, and category as well as inferential statistics using simple regression. Finding: It can be seen that the results of students' emotional quotient in the dominant category are good, and to think creatively has a good category. With a good EQ results affect the critical thinking skills of students who are appointed with a sig value obtained below than 0.025 , which is 0.020 and has a contribution of $71.6 \%$. Implications and Recommendations: According to the results, it is recommended that students need to be allowed to develop experience and linear thinking in learning activities. Teachers must utilize learning strategies so that they can create a variety of skills and learning attitudes from students for life.
\end{abstract}

Keywords Emotional Quotient, Creative Thinking, Students

\section{Introduction}

The need for the 21 st century in the curriculum of educational institutions is oriented to create productive, creative, innovative, and effective generations through the integration of attitudes, abilities, and knowledge with life skills [1]; [2]. Therefore educational institutions in a country determine competency as the goal of curriculum objectives [3]; [4]. Besides, teacher education practitioners agree that teacher education aims at educating high-quality teachers who will be successfully integrated into the education system [5]; [6]. Future global teacher school competencies are expected to include the knowledge base, skills, and attitudes they need to effectively carry out their professional duties in school and function profitably in a changing and interdependent society [7]; [8].

In learning, attitude is also an aspect that deserves to be taken into account. In the learning process, especially in mathematics lessons, participants' attitudes are essential to be rejected [9]. The attitudes of the process are fundamental [10]; [11]. Because students who have this view will have different attitudes, with students who have a positive outlook during the learning process [12]. In Learning cognitive and affective aspects are needed because students who have high affective will make these students find the self, critical, and creative concepts of a student. Attitude can be defined as a tendency to give a learned, consistent, positive, or negative reaction to an object [13]; [14]. [15] defines attitude as part of an individual's personality influenced by the behavior of the relationship with him. Attitude can also be described as a tendency to act towards people, things, events, or ideas. Attitudes appear to be unconscious, sustainable, and closely related to opinions. Attitudes are formed as a result of learning experiences that will foster emotional quotient from a student.

The environment strongly influences emotional quotient, is not sedentary, can change at any time. For this reason, the role of the situation, especially parents in childhood, is very influential in the formation of emotional quotient. EQ skills are not opposed to IQ skills or cognitive skills, but both interact dynamically, both at the conceptual level and in the real world. Also, EQ is not so influenced by heredity [16]. [17] said that it is not only one type of monolithic intelligence that is important for success in life, but there is a broad spectrum of 
intelligence with seven main varieties, namely linguistics, mathematics/logic, spatial, kinesthetic, music, interpersonal and intrapersonal. Gardner names this intelligence as personal quotient, which Daniel Goleman calls emotional quotient. According to Goleman, own intelligence consists of: "interpersonal intelligence, that is, the ability to understand others, what motivates them, how they work, how to work hand in hand with intelligence. While intrapersonal intelligence is a correlative ability but directed into the self, that ability is the ability to form a careful model of oneself and to refer to oneself and the ability to use that capital as a tool to live effectively" [17]. In another formulation, Gardner states that the core of interpersonal intelligence includes "the ability to distinguish and respond appropriately to the moods, temperaments, motivations, and desires of others." In interpersonal intelligence, which is the key to self-knowledge, he includes access to feelings of feelings one's self and the ability to distinguish between these feelings and use them to guide behavior [17]. Emotional intelligence plays a role not only in a child's school readiness and academic success but also in the adult's success in the workplace and marital relationships [18]; [19]; [20].

In addition to the affective aspects, the curriculum now also emphasizes cognitive aspects, especially on creative thinking skills. Although creative thinking includes cognitive and affective elements like other ways of thinking, it mainly involves the use of cognitive processes [21]. Because mathematics is focused on practicing ways of thinking and reasoning, developing creative activities, developing problem-solving abilities, and communicating ideas. Creative thinking skills are inherent to normative cognitive functioning rather than an innate talent available to only a few [22]; [23]. Importantly, various behavioral studies have shown that creative thinking skills can be enhanced [24]; [25]; [26]; [27]; [28]; [29]; [30]. Efforts made can be seen in terms of the material, the learning process, improvement, and support of infrastructure, increasing the ability of teachers to teach through upgrading or training, reduction or distribution of materials into simpler parts (simplification of material contained in the curriculum) or improved quality of input (students) in schools. Scientists, Teachers, and engineers cannot solely rely on their technical knowledge but will also be expected to have skills in areas such as problem-solving, creative thinking, written and oral communication, and teamwork [31]; [32]. Approach to overcome these problems, researchers put more emphasis on the learning process, because the process is the task and the professional responsibility of the teacher every day and will have an impact on the tasks in the next class. When referring to the identification of the causes of these weaknesses, the learning process requires ways that encourage students to understand the problem, enhance students' creative thinking skills in preparing a solution plan, and actively involve students in finding their problems, and encourage student-centered learning only as a facilitator.

The absence of critical and creative thinking in high school and the lack of motivation and interest to learn, especially in the subjects of science, is becoming a more common reality nowadays [33]. In the context of learning, [34] states that the ability to think creatively is closely related to the way teachers teach in schools. In the sense that the teacher becomes the main character in the school and parents become the determinant in the home and environment in fostering children's creativity. However, the reality on the ground shows that learning is done by teachers, especially mathematics teachers, still applies the old paradigm of the dimensions of cognitive processes. In this case, in learning, the teacher still relies on six processes, namely: memory, understanding, application, analysis, synthesis, and evaluation. [35] argues that the definition of mathematical creativity that is built in the western world is a process that opens new doors, is unusual and knowledge/insight is built through problem-solving, while according to views in the eastern world creativity focuses on re-interpretation of an issue which is viewed from a different angle. The definition of creativity proposed by [36] is a particular domain of thought process used by mathematicians when they solve non-routine mathematical problems.

Creative thinking skills in all domains, including science, technology, medicine, and art, emerged from the operation of the mental base on different things whose concepts are mixed because creative ideas are always a new combination of old ideas [37]. Cognitive abilities that include mastery of scientific concepts and facts in mathematics learning also need to be trained as a basis for training students' creative thinking skills [38]. Thinking abilities are categorized as necessary thinking skills and complex thinking abilities [39]. Basic thinking ability includes basic processes, which is a picture of rational thought processes that contain a set of mental processes from simple to complex. The necessary thinking ability process includes causation, transformation, relationship, classifications, and qualifications. Complex thinking skills are thinking abilities that are based on basic thought processes. [40] mentions that there are at least four complex thinking processes that occur in a person, namely problem solving, decision making, critical thinking, and creative thinking. The ability to think is importantly possessed by every student, both at school and in everyday life. By having excellent thinking skills, students will have the capital to be able to solve problems that occur in their lives. Having the ability to think, or the ability to think skillfully according to [41], can build a democratic individual.

Therefore, the purpose of this study is to look at the effect of emotional intelligence on creative thinking skills with the following research questions: 
What are the results of emotional quotient students have?

What are the results of creative thinking skills possessed by students?

Is there an influence between emotional intelligence with creative thinking skills possessed by students?

\section{Materials and Methods}

\subsection{Research Design}

The research method used in this research is descriptive. Descriptive analysis describes attitudes and behaviors observed during investigations, descriptive research taking place in natural, real-life settings [42]; [43]. The descriptive approach is taken to see the extent of emotional quotient possessed by students. Next, to find out the students' creative thinking skills. Then look at the effect of emotional quotient on students' creative thinking skills.

\subsection{Research subject}

The sample of this research was obtained from 82 students with Junior High School in Jambi students who were taken by purposive sampling technique with details of 48 female students and 34 male students with purposive sampling. Purposive sampling is a technique for sampling based on the criteria of the researcher [44]. The criteria in this study are students with the best five ranks.

\subsection{Research Instrument}

Research data obtained from the results of tests of creative thinking skills and questionnaires from emotional intelligence. The research instrument is used to measure creative thinking skills, which is an essay test, with a total of 12 questions. The creative thinking skills test was adapted from [45] with a scale of 0 - 4 where score 1 is very bad, score 2 is not good, score 3 is good, and score 4 is very good using 3 indicators, namely fluency, flexibility, and originality. Whereas the emotional quotient questionnaire was adapted from [46] with 30 valid questions with a reliability value of 0.73 with a using a Likert scale of 4 (five) for positive statements Strongly Disagree having a score of 1 , Disagree having a score of 2, Agree has a score of 3 and Strongly Agree 4. For negative statements Strongly Disagree has a score of 4, Disagree has a score of 3, a score of 2, and Strongly Agree has a score of 1 . While critical thinking uses essays on fluency indicators, 4 questions, flexibility 4 questions, and Originality of 4 questions, and using structured interviews aimed at strengthening quantitative data.

The data used by the SPSS program to look for descriptive and inferential statistics. Descriptive statistics are presented in a summary frequency, for example, mode, mean, median, minimum, maximum, and standard deviation [42]. Statistical inference from mathematical procedures for using probabilities and information about samples to conclude the population from which the sample is presumably was drawn [47]. In this study, there is a hypothesis test, the hypothesis using simple regression.

The categories of essay test include very good, good, not good, and very not good, like table 1 .

Table 1. Categories of Creative Thinking

\begin{tabular}{|c|c|c|c|}
\hline \multirow{2}{*}{ Category } & \multicolumn{3}{|c|}{ Interval } \\
\cline { 2 - 4 } & Fluency & Flexibility & Originality \\
\hline Very Not Good & $4.0-7.0$ & $4.0-7.0$ & $4.0-7.0$ \\
\hline Not Good & $7.1-10.0$ & $7.1-10.0$ & $7.1-10.0$ \\
\hline Good & $10.1-13.0$ & $10.1-13.0$ & $10.1-13.0$ \\
\hline Very Good & $13.1-16.0$ & $13.1-16.0$ & $13.1-16.0$ \\
\hline
\end{tabular}

The categories of emotional questions include very good, good, not good, and very not good, like table 2 .

Table 2. Categories of Emotional Quotient

\begin{tabular}{|c|c|}
\hline \multirow{2}{*}{ Category } & Interval \\
\cline { 2 - 2 } & Emotional \\
\hline Very Not Good & $30.0-52.5$ \\
\hline Not Good & $52.6-75.0$ \\
\hline Good & $75.1-97.5$ \\
\hline Very Good & $97.6-120.0$ \\
\hline
\end{tabular}

During data collection, the first activity that must be done is to select students based on the categories provided by the researcher, then give essay test for creative thinking and questionnaire of emotional quotient to students, the test and questionnaire is then processed using SPSS 21 application data to see descriptive statistics, in the form of, the mean, min, max, percentage, and category of students and see if there is an impact between the two variables.
Essay test of Creative Thinking and Emotional Quotient

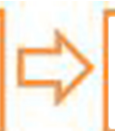

Results

Figure 1. Data Collection

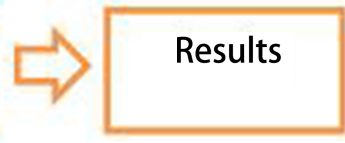




\subsection{Analysis Data}

All data were obtained from the essay test and EQ questionnaires on student values and collected and calculated and assisted with the SPSS 21 application. Descriptive statistics are given to calculate the frequency, percentage, mean, median, min, and max of a sample [43]. In this study, quantitative data were analyzed using parametric statistics of the simple regression to determine whether there is an impact between student emotional quotient (EQ) and students' creative thinking skills. This study uses SPSS 21 at the significance level of 0.025 . And followed by interviews that are used to strengthen the results of quantitative data. Followed by interviews intended to strengthen the results of quantitative data. The steps in the interview can be seen as follows: (1) the ideas, themes, pieces of data and words; (2) pay attention to patterns and themes; (3) try to make good data, using intuition to reach conclusion; (4) is a group set items into categories, types, behavior, and classification?; (5) makes a metaphor that uses figurative language and connotative rather than literal and denotative language, animates data, reducing data, making patterns, aligning data, linking data with theory; (6) separate variables to decipher, differentiate and 'unpack' ideas, is move from drive to integration and obfuscate data; (7) surrendered specifically into the general, large number of variables under a small number of (frequently) unobserved hypothetical variables; (8) identifies and records relationships between variables; (9) finds an intervening variable: looks for another variable that seems to be a 'block' calculation for what is expected to be a strong relationship between variables; (10) the logical chain of evidence building: noting causality and making conclusions; (11) Creating conceptual/theoretical coherence: moving from a method to construct stories to explain phenomena [42].

\section{Results}

Students can be seen from the characteristics of students themselves, through feelings of pleasure, or mediocrity from students in solving problems when he is studying. In addition, it can also be seen from the like or not, motivated or not motivated, interested or not. Attitude is a term that reflects someone's pleasure, displeasure, or ordinary feeling towards something [46]. And emotional intelligence possessed by students is able to foster students' creative thinking skills. Because students' creative thinking skills are very important to have in all aspects of educational studies [47]. Where, in this study, what will be investigated is emotional intelligence and creative thinking skills of students.

\subsection{Fluency}

The results of the questions given and the results obtained using the SPSS 21 application can be seen in the table 3.

From table 3, which came from 82 respondents from junior high school students categorized both for men as many as 14 students and for women as many as 38 students with good categories, and after processing and obtaining the results using the SPSS program application, then, obtained for fluency in creative thinking has a good category of $51.2 \%$ for 43 students out of 82 total students, very good at $25.6 \%$ for a total of 21 students out of 82 total students. Not good at $18.3 \%$ for 15 students out of 82 total students, and very poor $4.9 \%$ for 4 students out of 82 total students. Of the 82 students having a Mean value of 74.0, a Maximum Value of 91, and a Minimum Value of 27.

Table 3. The Result of Indicator Fluency

\begin{tabular}{|c|c|c|c|c|c|c|c|c|}
\hline \multirow[b]{2}{*}{ Range } & \multicolumn{4}{|c|}{ Classification } & \multirow{2}{*}{ Mean } & \multirow{2}{*}{ Min } & \multirow{2}{*}{ Max } & \multirow{2}{*}{$\%$} \\
\hline & M & $\mathrm{F}$ & Creative & Total & & & & \\
\hline $4.0-7.0$ & 3 & 1 & Not very good & 4 & \multirow{4}{*}{74.0} & \multirow{4}{*}{27.0} & \multirow{4}{*}{91.0} & 4.9 \\
\hline $7.1-10.0$ & 7 & 8 & Not good & 15 & & & & 18.3 \\
\hline $10.1-13.0$ & 14 & 38 & Good & 42 & & & & 51.2 \\
\hline $13.1-16.0$ & 10 & 11 & Very good & 21 & & & & 25.6 \\
\hline TOTAL & 34 & 48 & & 82 & & & & 100 \\
\hline
\end{tabular}

Table 4. The Result of Indicator Flexibility in creative thinking

\begin{tabular}{|c|c|c|c|c|c|c|c|c|}
\hline \multirow[b]{2}{*}{ Range } & \multicolumn{4}{|c|}{ Classification } & \multirow{2}{*}{ Mean } & \multirow{2}{*}{ Min } & \multirow{2}{*}{ Max } & \multirow{2}{*}{$\%$} \\
\hline & M & $\mathrm{F}$ & Creative & Total & & & & \\
\hline $4.0-7.0$ & 2 & 0 & Not very good & 2 & \multirow{4}{*}{76} & \multirow{4}{*}{29.0} & \multirow{4}{*}{94.0} & 2.4 \\
\hline $7.1-10.0$ & 8 & 10 & Not good & 18 & & & & 21.9 \\
\hline $10.1-13.0$ & 14 & 25 & Good & 39 & & & & 47.6 \\
\hline $13.1-16.0$ & 10 & 13 & Very good & 23 & & & & 28.1 \\
\hline TOTAL & 34 & 48 & & 82 & & & & 100 \\
\hline
\end{tabular}




\subsection{Flexibility}

The results of the essay questions given and the results obtained using the SPSS 21 application can be seen in the table 4.

From table 4, which came from 82 respondents from junior high school students categorized both for men as many as 14 students and for women as many as 25 students in good category, and after being processed and the results obtained using the SPSS program application, then, obtained for flexibility in creative thinking has a good category of $47.6 \%$ for 39 students from 82 total students, very good at $28.1 \%$ for a total of 23 students out of 82 total students. Not good at $21.9 \%$ for 18 students out of 82 total students, and very poor $2.4 \%$ for 2 students out of 82 total students. Of the 82 students had a Mean value of 76.0, a Maximum Value of 94, and a Minimum Value of 29 .

\subsection{Originality}

The results of the questions given and the results obtained using the SPSS 21 application can be seen in the table 5.

From table 5, which came from 82 respondents of junior high school students categorized both for men as many as 14 students and for women as many as 27 students with good categories, and after processing and obtaining the results using the SPSS program application, then, obtained for originality in creative thinking has a good category of $50.0 \%$ for 41 students out of 82 total students, very good at $25.6 \%$ for a total of 21 students out of 82 total students. Not good at $20.7 \%$ for 17 students out of 82 total students, and not very good at $3.9 \%$ for 3 students out of 82 total students. Of the 82 students had a Mean value of 73.0, Maximum Value of 93, and Minimum Value of 29.

\subsection{Emotional Quotient Students}

The results of the questionnaire provided and the results obtained using the SPSS 21 application can be seen in the table 6.

From table 6, which came from 82 respondents from junior high school students categorized both for men as many as 14 students and for women as many as 35 students with good categories, and after processing and obtaining the results using the SPSS program application, then, obtained for originality in creative thinking has a good category of $59.8 \%$ for 49 students out of 82 total students, very good at $26.8 \%$ for a total of 22 students out of 82 total students, and not good at $13.4 \%$ for 11 students out of 82 total students. Of the 82 students had a Mean value of 86.5.0, a Maximum Value of 117, and a Minimum Value of 53.

Table 5. The Result of Indicator Originality in creative thinking

\begin{tabular}{|c|c|c|c|c|c|c|c|c|}
\hline \multirow[b]{2}{*}{ Range } & \multicolumn{4}{|c|}{ Classification } & \multirow{2}{*}{ Mean } & \multirow{2}{*}{ Min } & \multirow{2}{*}{ Max } & \multirow{2}{*}{$\%$} \\
\hline & M & $\mathrm{F}$ & Creative & Total & & & & \\
\hline $4.0-7.0$ & 3 & 0 & Not very good & 3 & \multirow{4}{*}{73} & \multirow{4}{*}{29.0} & \multirow{4}{*}{93.0} & 3.7 \\
\hline $7.1-10.0$ & 7 & 10 & Not good & 17 & & & & 20.7 \\
\hline $10.1-13.0$ & 14 & 27 & Good & 41 & & & & 50.0 \\
\hline $13.1-16.0$ & 10 & 11 & Very good & 21 & & & & 25.6 \\
\hline TOTAL & 34 & 48 & & 82 & & & & 100 \\
\hline
\end{tabular}

Table 6. The Result of emotional quotient

\begin{tabular}{|c|c|c|c|c|c|c|c|c|}
\hline \multirow[b]{2}{*}{ Range } & \multicolumn{4}{|c|}{ Classification } & \multirow{2}{*}{ Mean } & \multirow{2}{*}{ Min } & \multirow{2}{*}{ Max } & \multirow{2}{*}{$\%$} \\
\hline & M & $\mathrm{F}$ & Emotional & Total & & & & \\
\hline $30.0-52.5$ & 0 & 0 & Not very good & 0 & \multirow{4}{*}{86.5} & \multirow{4}{*}{53.0} & \multirow{4}{*}{117.0} & 0.0 \\
\hline $52.6-75.0$ & 9 & 2 & Not good & 11 & & & & 13.4 \\
\hline $75.1-97.5$ & 14 & 35 & Good & 49 & & & & 59.8 \\
\hline $97.6-120.0$ & 11 & 11 & Very good & 22 & & & & 26.8 \\
\hline TOTAL & 34 & 48 & & 82 & & & & 100 \\
\hline
\end{tabular}

Table 7. Results of Regression

\begin{tabular}{|c|c|c|c|c|c|}
\hline \multirow{2}{*}{ Variabel } & \multicolumn{2}{|c|}{ Unstandardized Coefficients } & $\begin{array}{c}\text { Standardized } \\
\text { Coefficients }\end{array}$ & t & sig. \\
\cline { 2 - 6 } & B & Std. Error & Beta & & \\
\hline 1 (Constant) & 15.261 & 3.251 & & 4.694 & .000 \\
\hline Creative Thinking & .139 & .114 & .123 & 1.218 & .020 \\
\hline
\end{tabular}




\subsection{The Regression}

For the results of the influence of EQ with students' creative thinking skills can be seen in table 7 .

From table 7, it can be seen the results of a simple regression test found that the regression equation is $\mathrm{Y}=$ $15.261+0.139 \mathrm{X}$. for the number of contributions from emotional quotient on creative thinking can be seen in table 8 below.

Table 8. Contribution from emotional quotient on creative thinking

\begin{tabular}{|c|c|c|c|c|}
\hline Model & R & R square & $\begin{array}{c}\text { Adjust R } \\
\text { Square }\end{array}$ & $\begin{array}{c}\text { Std. Error of } \\
\text { the Estimate }\end{array}$ \\
\hline 1 & .820 & .716 & .702 & 2.703 \\
\hline
\end{tabular}

The results of simple regression analysis showed that the value of coefficient of determination was $\left(R^{2}\right) 0.716$. This means that the contribution of emotional quotient to creative thinking skills is $71.6 \%$, while the remaining $28.4 \%$ is influenced by other variables.

\section{Discussion}

In recent years, studies on personal success stories have focused on the 'emotional quotient' (EQ) as a distinctive factor that comprises self-awareness, self-regulation, motivation, empathy and social skills [17]; [49]; [50]. The factor is also known as emotional intelligence. argues that more than 75 per cent of the distinctive elements for personal achievement are EQ competencies. Further, evidence increasingly shows that, at the higher levels of organizational hierarchy, EQ becomes more important.

EQ is distinct from the cognitive abilities of technical intelligence that can be measured by IQ, but is composed of abilities complementary to IQ. Nevertheless, EQ does not mean the domination of emotions over rational decisions or an alternative to IQ. On the contrary, it is complementary and a synergic ally of IQ. EQ is simply the rational utilization of emotions [41]; [51]. These results are consistent with the opinion of [17], which states that emotional intelligence is the ability of a person to manage his emotional life with intelligence (to manage our emotional life with intelligence), emotional harmony alignment and disclosure (the appropriateness of emotion and its expression) through self-awareness skills self-control, self-motivation, empathy and social skills. Thus undeniable emotional intelligence is a development that needs to be nurtured and channeled to support the success of learning for students in the present and future.

To find out the ability of students to think creatively in problem solving based on Wallas's theory (1962) because it is one of the most commonly used theories to find out the creative thinking process of the inventors and arts workers which is interpreted as the ability of students to solve problems in mathematics. [52] argues that problem-solving is a process that occurs in four phases, namely; (1) Preparation, (2) Incubation, (3) Illumination, (4) Verification. According to [53] emotional intelligence consists of five main areas, namely (1) self-awareness, (2) self-regulation, (3) motivation, (4) empathy, and (5) social skills. The ability to motivate themselves in each student is not the same, each student has a different emotional intelligence.

According to the results in table 2, table 3 , and table 4 , all students showed satisfactory performance. However, according to the observations we made before conducting the study, we found that they had difficulty in solving the problem. That is caused by teachers who only use traditional methods during learning. Finally, we assume that students who are taught using conventional methods tend to obtain less than optimal performance [54]; [54]. If students have a good attitude, it will have a positive impact on the students' creative thinking. Where learning is a cognitive, affective and psychomotor characteristic, as an indicator that acts relatively stable for learning that is interconnected and reacts to the learning environment [56].

Creative and critical thinking are both essential for students in all aspects of educational studies [47]. Being creative is a universal human attribute. However, the representation of creative abilities would have both local as well as global cultural influences [57]; [58]. Teaching design is to help students to obtain creative achievements through developing their integrative abilities of comparison, analysis, and imagination. The relationship between effective teaching evaluations and teaching activities is active. Evaluations on students 'learning behaviors and learning results help to understand students' learning characteristics, interests, and learning achievements, to determine their learning effectiveness and to propose supplement teaching based on diagnosis, to develop creativity and encourage learning motivation [59].

A creative personality dares to engage in uncertain and ambiguous situations, find new aspects in something that is congenial and familiar and create new experiences, always eagerly searching for new styles and manners and proceedings with various stages of the creative process [60]; [61]; [62]. The characteristics of creativity are defined as being aware of one's own unity and coherence and evaluating the conditions for uniting the knowledge the person uses in the framework of this awareness, understanding the information obtained through observations and experiments, and making it ready to be used, perceiving the problem very quickly and making decisions quickly associating it with his imagination [63]; [64].

\section{Conclusions}

It can be seen that the results of emotional quotient 
students have a good category because, with students having good emotional intelligence, it will affect students in their learning, because emotional intelligence is one of the important factors that students must have. With students having good emotional intelligence, so when the learning process students will have more attention in learning that will have an impact on the benefits to be received by students, one of them has creative thinking skills. This is also supported by the relationship between students' emotional quotient (EQ) and creative thinking skills that have a significant relationship. According to the results, it is recommended that students need to be given the opportunity to develop direct experiences and thoughts in learning activities. Teachers must utilize learning strategies in order to develop a variety of learning skills and attitudes from students for life.

\section{Acknowledgments}

The researcher thanked the principal of the junior high school in Jambi which was the place of the study and became a sample of this research, and all parties involved.

\section{REFERENCES}

[1] Andrini, V. S. (2016). The effectiveness of inquiry learning method to enhance students' learning outcome: A theoritical and empirical review. Journal of Education and Practice, 7(3), 38-42.

[2] Siburian, J., Corebima, A. D., Ibrohim., \& Saptasari, M. (2019). The Correlation between Critical and Creative Thinking Skill on Cognitive Learning Results. Eurasian Journal of Educational Research. 81, 99-114.

[3] Pantic, N \& Wubbels, T. (2012). Competence-based teacher eduation: A change from Didaktik to Curriculum culture. Journal of Curriculum Studies. 44 (1). 61-87, DOI: 10.1080/00220272.2011.620633.

[4] Unlu, Sahika. (2018). Curriculum Development Study for Teacher Education Supporting Critical Thinking. Eurasia Journal Educational Research, 76, 165-186.

[5] Ezer, H., Gilat, I \& Sagee, R. (2010). Perception of teacher education and professional identity among novice teachers. European Journal of Teacher Education. 33(4). : 391-404. DOI: $10.1080 / 02619768.2010 .504949$

[6] Boonjeam W., Tesaputa K., \& Sri-ampai A (2017). Program development for primary school teachers' critical thinking. International Education Studies, 10(2), 131-138.

[7] Dobber, M., Vandyck, I., Akkerman, S, Graaff, D, R, Beishuizen, J., Pilot, A., Verloop, N \& Vermunt, J. (2013). The development of community competence in the teacher education curriculum. European Journal of Teacher Education, 36(3): 346-363.http://dx.doi.org/10.1080/02619768.2012.718326
[8] Signagatullin, I. M. (2019). Developing Preservice Elementary Teachers' Global Competence. International Journal of Educational. 28(1), 48-62, DOI:10.1177/1056787918824193

[9] Kurniawan, D. A., Darmaji., Astalini., Sefiah, P. (2019). Description of Science Process Skills for Physics Teacher's Candidate. Azerbaijan Journal of Educational Studies. 684(3), 71-85.

[10] Kurniawan, D, A., Astalini., \& Anggraini,L. (2018). Evaluasi Sikap SMP Terhadap IPA di Kabupaten Muaro Jambi. Jurnal Ilmiah Didaktika: Media Ilmiah Pendidikan dan Pengajaran. 19(1), 123-139.

[11] Astalini, A., Darmaji, D., Kurniawan, D. A., Melsayanti, R. (2019). E-Assessment of Student Perception of Natural Science Based on Seska in Middle School Students in Indonesia. International Journal of Scientific \& Technology Reseaerch, 8(9), 858-863.

[12] Astalini., Kurniawan, D. A., Sulistiyo, U., Perdana, R., Susbiyanto, S. (2019). E-Assessment Motivation in Physics Subjects for Senior High School. International Journal of Online and Biomedical Engineering (iJOE). 15(9), 4-15.

[13] Maison, Darmaji, Astalini, Dwi Agus Kurniawan, Peni Sefiah Indrawati. (2019). Science Process Skills and Motivation. Humanities \& Social Science Reviews (HSSR), 7(5), 48-56.

[14] Bulunuz, N., Bulunuz, M., Orbak, A. Y., Mulu, N., \& Tavşanlı, Ö. F. (2017). An evaluation of primary school students' views about noise levels in school. International Electronic Journal of Elementary Education, 9(4), 725-740.

[15] Astalini, Kurniawan, D. A., Darmaji., Sitorus, L. R., Perdana, R. (2019). Characteristic of Students Attitude to Physics in Muaro Jambi High School. Humanities \& Social Science Reviews. 7(2), 91-99.

[16] Shapiro, L. E. (1998). How to raise a child with high Emotional Quotient-A Guide to Emotional Intelligence.

[17] Goleman, D., Boyatzis, R. and McKee, A. (2002) 'The Emotional Reality of eams', Journal of Organizational Excellence, 21(2): 55.

[18] Bharwaney, G., Bar-On, R., \& MacKinlay, A. (2007). EQ and the bottom line. London: Ei World.

[19] Cilliers, F., \& Dahl, D. (2012). The relationship between cognitive ability, emotional intelligence and negative career thoughts: A study of career-exploring adults. SA Journal of Human Resource Management, 10(2), 1-14.

[20] Louw, D., \& Louw, A. (2007). Die ontwikkeling van die kind en adolessent. Bloemfontein, Suid-Afrika: Die Universiteit van die Vrystaat.

[21] Bacanli, H., Dombayci, M. A., Demir, M., \& Tarhan, S. (2011). Quadruple Thinking: Creative Thinking. Procedia Social and Behavioral Science. 12, 536-544.

[22] Ward, T.B., Smith, S.M., Finke, R.A., (1999). Creative cognition. In: Sternberg, R.J. (Ed.), Handbook of Creativity. Cambridge University Press, Cambridge, pp. 189-212. 
[23] Colzato, L. S., Ritter, S. M., \& Steenbergen, L. 2018. Transcutaneous Vagus nerve stimulation (tVNS) enhances divergent thinking. Neuropsychologia, 111, 72-76.

[24] Baas, M., Nevicka, B., \& Ten Velden,F. S. 2014. Specific mindfulness skills differentially predict creative performance. Personal. Social. Psychol. Bull. 40 (9), 1092-1106.

[25] Colzato, L.S., Ozturk, A., \& Hommel, B., 2012. Meditate to create: the impact of focusedattention and open-monitoring training on convergent and divergent thinking. Front. Psychol. 3, 116.

[26] Colzato, L.S., Szapora Ozturk, A., Pannekoek, J.N., \& Hommel, B., 2013. The impact of physical exercise on convergent and divergent thinking. Front. Human. Neurosci. 7, 824.

[27] Colzato, L.S., de Haan, A.M., \& Hommel, B., 2015. Food for creativity: tyrosine promotes deep thinking. Psychol. Res. 79 (5), 709-714.

[28] De Bloom, J., Ritter, S., Kühnel, J., Reinders, J., \& Geurts, S., 2014. Vacation from work: a 'ticket to creativity'? the effects of recreational travel on cognitive flexibility and originality. Tour. Manag. 44, 164-171.

[29] Ritter, S.M., \& Mostart, N., 2016. Enhancement of creative thinking skills using a cognitivebased creativity training. J. Cogn. Enhanc. 1, 1-11.

[30] Zabelina, D.L., \& Robinson, M.D., 2010. Child's play: facilitating the originality of creative output by a priming manipulation. Psychol Aesthet. Creat. Arts 4(1), 57.

[31] Passow, H.J., \& Passow, C.H., 2017. What competencies should undergraduate engineering programs emphasize? A systematic review. J. Eng. Educ. 106 (3), 475-526.

[32] Lynch, M., Kamovich, U., Longva, K. K., \& Steinert, M. (2019). Combining technology and entrepreneurial education through design thinking: Students' reflection on the learning process. Technological Forecasting \& Social Change. https://doi.org/10.1016/j.techfore.2019.06.015

[33] Rivas, P. G. (2017). Strategies for teaching and dissemination of artistic heritage by promoting critical and creative thinking among future Primary Education teachers. Procedia - Social and Behavioral Science, 237, 717-722.

[34] Ruggiero, V. R., \& Ruggerio, V. R. (2004). The art of thinking: A guide to critical and creative thought. Pearson/Longman.

[35] Kim, K. H. (2011). The creativity crisis: The decrease in creative thinking scores on the Torrance Tests of Creative Thinking. Creativity Research Journal, 23(4), 285-295.

[36] Chamberlin, S. A., \& Moon, S. M. (2005). Model-eliciting activities as a tool to develop and identify creatively gifted mathematicians. Journal of Secondary Gifted Education, 17(1), 37-47.

[37] Ghonsooly, B., \& Showqi, S. (2012). The Effects of Foreign Language Learning on Creativity. English Language Teaching, 5(4), 161-167.

[38] Hadzigeorgiou, Y., Fokialis, P., \& Kabouropoulou, M. (2012). Thinking about creativity in science education. Creative Education, 3(05), 603.
[39] Costa, A. L. (1985). Developing minds: A resource book for teaching thinking. Association for Supervision and Curriculum Development, 225 N. Washington St., Alexandria, VA 22314.

[40] Ristow, R. S. (1988). The Teaching of Thinking Skills: Does It Improve Creativity? Gifted Child Today Magazine, 11(2), 44-46.

[41] Dulewicz, V. and Higgs, M. (2000) 'Emotional Intelligence: A Review and Evaluation Study', Journal of Managerial Psychology, 15(4): 341-73.

[42] Cohen, L., Manion, L., \& Morrison, K. (2007). Research Methods in Education: Routledge.

[43] Creswell, John W. (2012). Educational Research: Planning, Conducting, and Evaluating Quantitative and Qualitative Research. New York: Pearson

[44] Kerlinger, F. N. (2014). Foundations of behavioral research. Yogyakarta: Gadjah Mada University Press.

[45] Treffinger, D. J., Young, G. C., Selby, E. C., \& Shepardson, C. (2002). Assessing creativity: A guide for educators. The National Research Center on the Gifted and Talented. Center for Creative Learning, Sarasota: Florida

[46] Goleman, D. (2005). Emotional Intelligence. Why" EQ" is more important than" IQ. Varlık Publications, İstanbul, Turkey.

[47] Gall.D.M et al. (2003). Education Research an introduction seventh edition. USA: Pearson Education.Inc

[48] Astalini, A., Darmaji, D., Kurniawan, D. A., Melsayanti, R. (2019). E-Assessment of Student Perception of Natural Science Based on Seska in Middle School Students in Indonesia. International Journal of Scientific \& Technology Reseaerch, 8(9), 858-863.

[49] Piaw, C. Y. (2011). Hindrances to Internal Creative Thinking and Thinking Styles of Malaysian Teacher Trainees in the Specialist Teachers' Training Institute. Procedia Social and Behavioral Sciences. 15, 4013-4018.

[50] Cramer, D. (2003). Advanced quantitative data analysis. McGraw-Hill Education (UK).

[51] Goleman, D. (1998) Working with Emotional Intelligence. New York: Bantam Books.

[52] Salopek, J.J. (1998) 'Train Your Brain', Training \& Development, 52: 26-34.

[53] Weisinger, H. (1998) Emotional Intelligence at Work: The Untapped Edge for Success. San Francisco, CA: Jossey-Bass.

[54] Jamaris, M. 2013. Orientasi Baru dal-am Psikologi Pendidikan. Bogor: Ghalia Indonesia.

[55] Duran, M., \& Dökme, İ. (2016). The effect of the inquiry-based learning approach on student's critical-thinking skills. Eurasia Journal of Mathematics, Science \& Technology Education, 12(12), 2887-2908.

[56] Wartono, W., Hudha, M. N., \& Batlolona, J. R. (2018). How are the physics critical thinking skills of the students taught by using inquiry-discovery through empirical and theorethical overview. Eurasia Journal of Mathematics, 
Science and Technology Education, 14(2), 691-697.

[57] Keefe, J. W., \& Walberg, H. J. (1992). Teaching for Thinking. National Association of Secondary School Principals, 1904 Association Drive, Reston, VA 22091-1537.

[58] Mpofu, E., Myambo, K., Mogaji, A. A., Mashego, T.-A., \& Khaleefa, O. H. (2006). African perspectives on creativity. In J. C. Kaufman, \& R. J. Sternberg (Eds.). The international handbook of creativity. Cambridge: Cambridge University Press.

[59] Humble, S., Dixon, P., \& Mpofu, E. (2018). Factor structure of the Torrance Tests of Creative Thinking Figural Form A in Kiswahili speaking children: Multidimensionality and influences on creative behaviour. Thinking Skills and Creativity, 27, 33-44.

[60] Lin, Ruilin. (2012). A Study of Curriculum Innovation Teaching and Creative Thinking for Picture Book Creation. IERI Procedia, 2, 30-35.

[61] Slahova, A., Savvina, J., Cacka, M., \& Volonte, I. (2007). Creative activity in conception of sustainable development education. International Journal of Sustainability in Higher Education, 8(2), 142-154.

[62] Chua, Y. P. (2009). Writing a series of best-selling research reference books. Journal of Scholarly Publishing, 40(4), 408-419.

[63] Piaw, C. Y. (2010). Building a test to assess creative and critical thinking simultaneously. Procedia Social and Behavioral Sciences, 2, 551-559.

[64] Özcan, A. O. (2000). Algidan yoruma yaratici düsünme. Istanbul: Avciol Basim Yayin.

[65] Özcan, Deniz. (2010). Contributions of English teachers' behaviours on students' creative thinking abilities. Procedia Social and Behavioral Sciences, 2, 5850-5854. 